\title{
From house mouse to mouse house: the behavioural biology of free-living Mus musculus and its implications in the laboratory
}

\author{
Naomi Latham*, Georgia Mason \\ Department of Zoology, Animal Behaviour Research Group, Oxford University, \\ South Parks Road, Oxford OX1 3PS, UK
}

\begin{abstract}
Understanding a species' behaviour in natural conditions can give insights into its development, responses and welfare in captivity. Here, we review research and pest control literatures on the free-living house mouse (Mus musculus), analysing its sensory world, developmental processes and behaviour to suggest how laboratory environments might affect mouse welfare, normalcy, test design, and behaviour. Mouse development from foetus to weaning is influenced by prenatal stress and nutrient levels, and post-natal litter size and other factors affecting maternal care, all with lasting effects on adult bodyweight, aggression, activity levels, stress responsiveness and masculinisation. These influences may well be important in the laboratory, for example unwittingly differing between facilities leading to site-differences in phenotype. Murine senses are dominated by olfactory, auditory and tactile cues. Their hearing extends into the ultrasonic, and vision, from mid-range wavelengths to the ultraviolet. In mouse facilities, behaviour and welfare may therefore also be affected by sensory stimuli unnoticed by humans. The physical and social environment and behaviour of wild mice differ greatly from those of laboratory mice. Dispersal age varies with resource-levels and social cues, and mice often either live alone or in family groups. Mice occupy territories/ranges measuring a few square meters to several square kilometers, and which allow running, climbing, and burrowing. Mice are often active during dawn/dusk, and spend their time patrolling their territories, investigating neighbours' odour cues, foraging, finding mates and rearing litters. The potential impact of these many differences and restrictions on laboratory mouse development, normalcy and welfare has only begun to be explored. (C) 2004 Elsevier B.V. All rights reserved.
\end{abstract}

Keywords: House mouse; Mus musculus; Sensory biology; Behaviour; Development; Welfare; Standardisation

\section{Introduction}

Understanding a species' natural biology and behaviour is important for good husbandry (e.g. Dawkins, 1980; Jensen, 2000; Mason et al., 2001). This has been acknowledged for

\footnotetext{
* Corresponding author. Tel.: +44-1865-271-214; fax: +44-1865-281-253.

E-mail address: naomi.latham@zoo.ox.ac.uk (N. Latham).
} 
laboratory species (Home Office, 1986; Brain, 1992; Olsson et al., 2003), yet no up-to-date, detailed review exists for the free-living house mouse-even though mice are the most common research animal, with a world population of 30 million and rising (Mason and Latham, 2004). Our aim is to use a diverse array of peer-reviewed research papers, plus pest control publications (not refereed, but based on practical experience), to describe how free-living house mice view and interact with their world, and to illustrate how physical and social environments influence their development and behaviour. We conclude by discussing the implications of these findings for mouse welfare and functioning in laboratory conditions, and how subtle housing and test effects may lead to unexplained variance in research results.

\section{Adaptability and sensory biology of the house mouse}

The term 'house mouse' has been applied to several species, but most laboratory mice are likely to descend from Mus musculus (Linné's house mouse-Staats, 1975). The house mouse has spread around the globe as our parasite, and now occurs in two types of situation-commensal, where it depends on humans for food and shelter, and feral, where it lives more like other wild rodents (e.g. reviewed Gray and Hurst, 1998). Mus musculus is one of the most widespread mammalian species on the planet (e.g. Meehan, 1984), being found in all tropical and temperate regions apart from tropical Africa (Schwartz and Schwartz, 1943; Berry, 1970).

The success of the house mouse stems from partly from its great adaptability. Mice can survive without free water if their food is has a water content of $15 \%$ (including foods as dry as flour; Southern, 1954; Fertig and Edmonds, 1969); they can live and breed in cold stores as cool as $-30^{\circ} \mathrm{C}$ (Randall, 1999); and have been found living in mines, at depths of $600 \mathrm{~m}$ (see Bronson, 1979). They are highly adapted to omnivory, and are able to chew through tough husks and shells (Baumans, 1999). This ability stems from powerful masseter muscles, and permanently sharp, chisel-like incisors that grow continuously by ca. $0.4 \mathrm{~mm}$ a day (Macdonald, 1984; Besselsen, 1997). Mice are very agile. They generally locomote via brief, rapid scurrying runs, but are also excellent climbers, capable of scaling vertical brickwork or bark (Randall, 1999); proficient jumpers, able to leap over $30 \mathrm{~cm}$ vertically upwards, and $2.5 \mathrm{~m}$ downwards, without harm (Randall, 1999); and capable swimmers (Randall, 1999; MAFF, 1996). They can run along wires and narrow ropes with ease (Meehan, 1984; Randall, 1999), and squeeze through cracks as narrow as $5 \mathrm{ml}$ (Potter, 1994; Randall, 1999). Mice also show a wide range of developmental flexibility, their early experience affecting phenotype in a way that may ensure pups develop into adults best suited for their local environments. Finally, mice are highly genetically adaptable. Rodents have higher mutation rates than other mammalian orders (Page and Holmes, 1998). This, combined with the house mouse's rapid and prolific breeding rates, means that populations are able to adapt rapidly to new conditions (e.g. Macdonald, 1984). Naturally occurring genetic differences are claimed in behaviours including aggression and territoriality (e.g. van Zeegeren, 1980; Brain and Parmagiani, 1990; Benus and Rondigs, 1996), and burrowing and nest-building (e.g. Lynch, 1980 cited by Crawley, 2000; Sage, 1981 cited by Meehan, 1984; Sluyter and van Oortmerssen, 2000). These traits all help account for the prevalence of the mouse as both a free-living and laboratory animal. 
Murine sensory biology has been reviewed elsewhere (Olsson et al., 2003), so will only be recapped here. The mouse's world is dominated by smell (e.g. Lawlor, 1994). Odours are used to detect and assess food and predators, recognise individuals, and to evaluate conspecifics' sexual and social status (e.g. Berry, 1970). Their other chemo-sense, taste, appears broadly similar to our own, although mice do not respond to some compounds which taste sweet to us (Brouwer and Hellekant, 1973 cited by Meehan, 1984) and ingest substances which we find disgustingly bitter (e.g. 'Bitrex'; Rentokil, 2001). Taste is used to identify food type and quality (Crawley, 2000): crucial as mice cannot vomit if food proves dangerous (Rentokil, 2001).

Mice are very sensitive to touch. Their whiskers, actively moved in a manner termed 'whisking', send tactile information to specialised 'whisker barrels' in the neocortex (e.g. Melzer and Smith, 1998), allowing mice to identify textures, and avoid obstacles, even when light levels are too low to see (Lawlor, 1994). The body's touch-sensitive guard hairs are also used to sense overhead cover, and when moving along walls (Meehan, 1984; Randall, 1999). Such tactile contact is important to mice, which generally attempt to retain bodily contact with solid objects (thigmotaxis), especially when anxious (Mackintosh, 1981; Lawlor, 1994).

Mouse vision is fairly well-developed (Crawley, 2000), but their acuity is poor compared with humans (Jennings et al., 1998; Baumans, 1999). Mice are very sensitive to movement and changes in light intensity, and also use visual cues to demarcate territorial boundaries (Mackintosh, 1973), to navigate, or move to cover (e.g. Hopkins, 1953; Chapillon, 1999). Their retinas are composed mainly of rods, giving them sensitive vision in dim light, but little colour perception (Calderone and Jacobs, 1995; Crawley, 2000). Furthermore, their cones' peak spectral sensitivities differ from those of humans. They lack a long-wave photopigment (causing insensitivity to red wavelengths), but are sensitive to ultraviolet wavelengths (Lawlor, 1994; Calderone and Jacobs, 1995). Mice are thus likely to perceive hue differently to humans. Ultraviolet sensitivity may be an adaptation to crepuscular activity (e.g. Tovée, 1995), and may be used in navigation (N. Prescott, personal communication), and in foraging - as many fruits, seeds and even larvae reflect in ultraviolet (Tovée, 1995; Church et al., 1998).

Finally, mice have well-developed hearing, and are able to hear noises from ca. $10 \mathrm{kHz}$ to ultrasounds over $100 \mathrm{kHz}$ (Lawlor, 1994; Baumans, 1999). In rats, there is some evidence that ultrasonic calls are used in echolocation and judging the depth of drops in darkness (e.g. Kaltwisser and Schitzler, 1981). Such behaviour has yet to be confirmed in mice, but might help explain why despite their limited visual abilities their depth perception is good, allowing them to make long and accurate jumps (Meehan, 1984).

\section{House mouse behaviour in natural conditions}

\subsection{From birth to weaning: development and factors affecting final adult phenotype}

House mice are born blind, deaf and completely hairless, except for small whiskers on the muzzle (Berry, 1970; Smith, 1981). Their first physical environment is a secluded nest. For feral mice, this is in an underground nest chamber, typically 6-7 cm across, lined with grass, 
hair or feathers (e.g. Berry, 1970). Commensal pups are raised in a spherical or bowl-shaped nest, located in a safe nook, consisting of a loose outer structure of rags or paper about $10 \mathrm{~cm}$ across, lined with a finer, shredded material (Randall, 1999; Nowak, 1999). At first, their social environment consists of 4-8 littermates, typically of equal sex ratio (Berry, 1970; Berry and Bronson, 1992) and their mother, although some pups may also be suckled by other, usually related, breeding females. As they develop, their social environment may expand to include their father (the dominant male), older brothers and sisters who have not yet dispersed, and/or less closely related conspecifics. This family unit is called a 'deme' (e.g. van Zeegeren, 1980).

From birth through the first 2-3 weeks of age, pups rely on the mother for temperature regulation, food and to stimulate defecation (Clough, 1982; Berry and Bronson, 1992). Unable to thermoregulate fully until between 12 and 28 days (see Clough, 1982; Berry and Bronson, 1992), newborn litters usually form a 'dynamic huddle', in which pups continually burrow into the centre of the group to conserve heat (Smith, 1981). Newborn pups probably use tactile, olfactory and gustatory cues to recognise and orient to the mother and her teats (Smith, 1981; Fleming et al., 2002). The pups stimulate parental behaviours through specific vocal cues (Mackintosh, 1981; Smith, 1981; Lawlor, 1994) such as 'wriggling calls' (below $10 \mathrm{kHz}$ ), produced when struggling in the nest or pushing to attach to the teats (Crawley, $2000)$, and short duration ultrasonic calls $(50-70 \mathrm{kHz},<300 \mathrm{~ms})$, produced when pups are separated from the mother and are cold or distressed (Smith, 1981; Roberts, 1998).

Mouse pups grow and develop rapidly. They develop pigmentation within a few days, start growing fur within a week (Horn, 2000), begin to show auditory responses at 11 days (Smith, 1981), and by 12 days can identify their mother's smell (Smith, 1981). At 14-15 days their eyes open, although their vision is not fully developed until approximately 2 weeks later (Smith, 1981). Pups learn about the food eaten by their mother long before they are weaned off milk (Valsecchi et al., 1993; Lawlor, 1994), and begin to try this solid food themselves between 10 and 17 days (König and Markl, 1987; Horn, 2000). Pups are cautious about trying novel foods, but during grooming continue to assess foods eaten by other familiar adults and are most willing to try new foods known to be eaten by them (Valsecchi et al., 1996; Choleris et al., 1997; Crawley, 2000).

At 3-4 weeks of age, pups begin to venture away from the nest (Berry, 1970; Randall, 1999), but their early exploratory trips are brief, and usually accompanied by a parent (Crowcroft, 1966). At this age, the young usually become nutritionally independent of their parents, when they typically weigh nine grams (König and Markl, 1987; Mendl and Paul, 1991a). However, if pups have grown slowly, for example if the litter is large, independent feeding may be delayed until as late as 35 days (König and Markl, 1987; Mendl and Paul, 1991a; Drickamer et al., 2000). Accompanying the mother on foraging trips allows the young to learn more about diet selection (Choleris et al., 1997). As they grow in confidence, their trips become longer, unchaperoned and playful (Brown, 1953; Crowcroft, 1966), with sib groups exploring, as well as foraging, together (reviewed Choleris et al., 1997). After weaning, the pups usually remain in the natal nest for an additional few weeks, until they reach sexual maturity (Brown, 1953; Berry, 1970).

Throughout pup-hood, and even in utero, house mice show impressive developmental plasticity, with many aspects of the early environment having lasting effects on adult phenotypes. Maternal stress during gestation reportedly slows post-natal development (e.g. 
Meek et al., 2001) and influences (generally increasing) later response to stressors (e.g. reviewed Braastad, 1998). Furthermore, prenatal stress can induce masculinisation of female pups (Zielinski et al., 1991) and feminisation of male pups (Kinsley and Svare, 1988), which potentially decreases later aggression, fertility and territorial success in males (e.g. Harvey and Chevins, 1985; Kinsley and Svare, 1986), and alters females' later oestrous cycling, reproductive success and offspring sex ratio (Vandenberg and Huggett, 1994; Palanza et al., 1995; Drickamer, 1996). Additionally, low food availability during gestation can decrease weaning weight and increase aggressiveness, influencing the adult social and sexual success of male offspring (Mendl and Paul, 1991b; Meikle et al., 1995; Meikle and Westberg, 2001). It can also alter litter size and sex ratio, resulting in either male-biased (at moderately low food availability) or female-biased (severe food deprivation) litters (Wright et al., 1988). Litter size and sex ratio can then have long-term influences on later social competence, parental behaviour, learning and aggression (Namikas and Wehmer, 1978; Barnard et al., 1998).

The quality of parental care during infancy can also have both short-term and lifelong consequences. For example, the amount of milk received can affect a pup's adult weight and aggressiveness (e.g. Mendl and Paul, 1991b; Barnard et al., 1998; see also Ryan and Wehmer, 1975). The weaning weight of male pups can have long-term effects on their ability to become dominant adults (Krackow, 1993), while litter size (and thus milk availability) affects the age at which they attain sexual maturity (Ryan and Wehmer, 1975). Parental care may also affect other endocrine systems. The amount of licking and grooming that rodent pups receive in infancy influences their later corticosterone responses to stress (Barnett and Burn, 1967; Hennessy et al., 1982; Roberts, 1998). Neonatal exposure to stressors, such as long separations from the mother, may increase ability to cope with stress during adulthood (see Lay, 2000; Cirulli, 2001). Finally, the amount of maternal licking that female pups receive can also influence how much they lick their own pups, once they are mothers themselves (see Fleming et al., 2002).

Other aspects of the social environment can further affect adult phenotype. Female pups reportedly develop activity levels similar to those of adult females whose urine they were exposed to (Cowley et al., 1990). The presence of, and cues from, the father may enhance aggressiveness of male offspring, and influence later sexual preferences of female offspring (Mugford and Nowell, 1972). Finally, odours from the mother can influence later mate choice and parental behaviour (Hayashi and Kimura, 1983 cited by Meehan, 1984; Shah et al., in press cited by Fleming et al., 2002). Thus overall, pups' developmental trajectories vary from family to family and site to site, according to local circumstance.

\subsection{Sexual maturity and dispersal: different strategies for different individuals}

Sexual maturity typically occurs at 5-6 weeks of age, but can be delayed until as late as 12 weeks (e.g. van Zeegeren, 1980; Meehan, 1984; Henwood, 1995). Females generally mature earlier than males (Berry, 1970), but maturation rate is affected by genotype, with aggressive males generally being earliest to mature (van Zeegeren, 1980). Environmental factors can affect the timing of puberty. For example, females experiencing cold or crowded conditions may delay puberty until conditions become more favourable (see Berry, 1970). In females, chronic exposure to the urine of non-breeding adult females can delay puberty 
(Mugford and Nowell, 1972; Hurst, 1990; Hurst and Nevison, 1994), while exposure to male urine can accelerate it and increase the frequency of oestrous cycles, particularly if there is also tactile contact (see Mugford and Nowell, 1972; Smith, 1981; Brown, 1985). In males, exposure to females can advance puberty (Vandenbergh, 1971), but these effects are reported to be less pronounced (Smith, 1981).

As the young mice reach sexual maturity, family relationships change. Young males become more aggressive (Berry, 1970), and the father increasingly begins to attack his sub-adult sons (Bronson, 1979). Many young males now leave the familial nest to search for their own territory (e.g. Berry, 1970). Indeed, between the ages of 33 and 43 days, laboratory mice, especially young males, show a marked increase in exploration and novelty-seeking (e.g. Palanza et al., 2001). Whether to disperse, or to stay and strive to inherit the family territory, is often determined by the size and aggressiveness of the young males (van Zeegeren, 1980). At low population densities, aggressive males disperse at a relatively young age, while their more timid peers stay behind (van Zeegeren, 1980). At high population densities, the non-aggressive males disperse relatively early, while aggressive ones stay on as subordinates until the opportunity arises to displace their father (van Zeegeren, 1980). However, remaining in the parental territory is dangerous, because males that stay and are not strong enough to overthrow their father may well be killed (see e.g. Brown, 1953; Gerlach, 1990).

Young females face the same choice, but are at less risk of aggression if they remain with their parents. Many will always remain subordinate to the breeding female(s) and never produce litters of their own, their fertility being suppressed by sustained exposure to breeding-female urine (see above). However, they may help the breeding female(s) rear subsequent litters (Gerlach, 1990; Berry and Bronson, 1992; see also Hurst, 1987a), and some may eventually succeed in becoming breeders themselves.

\subsection{Choosing and establishing a territory}

For those young adults which disperse, we must imagine their movements from descriptions of captive mice exploring new environments. The first excursions into any new area are brief. Wherever possible, mice display thigmotaxis, following barriers and walls. This movement is initially interspersed with frequent pauses, during which they rear at walls and barriers or make long stretches forward, sniffing. Gradually they make longer excursions and brief ventures in more open areas to investigate objects of interest. In between each excursion, mice are likely to return to a 'safe' area, following visual landmarks and olfactory marks produced by plantar glands on the feet (Crowcroft, 1966; Alyan, 1996; Alyan and Jander, 1994). Despite their caution, dispersing mice can travel large distances, sometimes covering hundreds of metres nightly (Rowe et al., 1963; DeLong, 1967).

For dispersing feral mice, the goal is an area with dense ground cover (e.g. shrubs or herbaceous plants), a nest site offering protection from the cold and predators, and access to feeding sites (e.g. Meehan, 1984; Torre and Bosch, 1999). Mice are very efficient tunnellers in soft substrates (Gyertyan, 1995; Masuda et al., 2000; Deacon et al., 2001). Feral mice may live in burrows ranging from simple, straight tunnels, $1 \mathrm{~m}$ in length, ending in a single circular nest chamber, up to more complex systems linking numerous chambers and exits (Meehan, 1984; Berry and Bronson, 1992; Bourne, 1997). Mice will also take advantage of 
burrows dug by other animals, such as rabbits and puffins (Triggs, 1991; Gray and Hurst, 1998). However, if burrowing is impossible, for example if the soil is too hard or poorly drained (Newsome et al., 1976), feral mice make their nests above ground (Baker, 1946; Berry and Bronson, 1992). The main goal for dispersing commensal mice is, similarly, a protected site within which they can build a nest, for example behind rafters, in wall cavities, in storage areas, or other secluded areas near to food (e.g. Meehan, 1984; Surgeoner, 1986; Randall, 1999).

In their search for a territory, feral mice tend to avoid areas that have been cleared of vegetation, and rarely cross roads (see Meehan, 1984). Commensal mice similarly avoid unsheltered, exposed areas, and those that are regularly disturbed (e.g. Proctor, 1994). Males generally avoid, or act more cautiously in, sites scented with the urine of other males (Brown, 1985; Beynon and Hurst, 2000). Mice also seem to avoid other sites where there is a high risk of predation. They find carnivore faeces and related scents aversive (e.g. Kemble and Bolwahnn, 1997), and avoid the urine and faeces of recently-frightened conspecifics (e.g. Brown, 1985). For females, the local presence of a male, and status of his associated females, may also be important, as the breeding success of female mice is critically dependent on their ability to establish a nest-site within a male territory (reviewed Krackow, 1993).

Some young mice never establish their own territory. These, sometimes nomadic, nonterritory-holders (described as 'peripheral'; Anderson, 1970 cited by Meehan, 1984) tend to be the smaller animals (Mackintosh, 1978), and their lives are particularly tough. However, for other dispersers, finding a suitable site will be followed by settling, building a nest, and establishing territorial boundaries.

Territory size varies enormously. The main determinants are food availability and population density, and these in turn affect how territories are maintained and defended. When food is ample and population densities high, commensal mice may stray no more than a metre or two from their nest site (Potter, 1994; Randall, 1999), but territory size increases the more dispersed the food. Thus Southern (1954) found territories in a cellar ranging from 2 to $6 \mathrm{~m}^{2}$, while Young et al. (1950) found that individuals' capture points in a building population averaged four metres apart. The pest control literature also states that commensal mice can travel up to ten metres from their nest-sites, although rarely further than this (Surgeoner, 1986; Randall, 1999; DellPest, 2001). In feral populations, home range sizes also vary with density of available food (Krebs et al., 1995; Crawley, 2000), but tend to be larger. For feral mice, densities of around one mouse for every three square metres have been observed in fields of grain (Dickman, 1999). Home ranges have been estimated up to $365 \mathrm{~m}^{2}$ in size in open fields (Quadagno, 1968), an average of $6000 \mathrm{~m}^{2}$ in forests (Fitzgerald et al., 1981); a mean of $40,000 \mathrm{~m}^{2}$ on the Russian steppes (Nikitina et al., 1976 cited by Meehan, 1984); and up to an incredible $80,000 \mathrm{~m}^{2}$ in the wheat-lands of Australia (Chambers et al., 2000).

Commensal territories and feral home ranges differ in other ways too. As our terminology implies, they differ in how strictly they are defended. For example, in feral populations, male ranges tend not to overlap much with those of other males, nor female ranges with those of other females (e.g. Fitzgerald et al., 1981), but male and female ranges may overlap, sometimes completely, even if the respective male and female are not a breeding pair (Berry and Jakobson, 1974; Fitzgerald et al., 1981; Krebs et al., 1995). In commensal populations, males tend to divide all the available space into strictly defended, mutually exclusive territories, with minimal overlap and sometimes even vacant strips between territorial boundaries 
(Mackintosh, 1981; MAFF, 1996). In addition, commensal territories tend to be rather stable, while feral mice home ranges often fluctuate greatly in size, shape and even location with seasonal changes in habitat quality (Berry and Jakobson, 1974; Torre and Bosch, 1999).

Territorial boundaries often occur at physically and/or visually striking features of the environment (Crowcroft, 1966; Mackintosh, 1973, 1978). However, boundaries are also marked by urinary odour cues. Dominant male mice, in particular, lay down regular urine marks along their borders to provide information about their territorial and sexual status (e.g. Bronson, 1979; Hurst et al., 2001). Marks are also laid down along runs throughout the territory, and are especially common on conspicuous objects and around nesting and feeding sites (Hurst, 1987b, 1993). Thus mice become surrounded by familiar mark-odours (Hurst, 1990), and there is even evidence that some mice may use urinary odour gradients to anticipate edges and drops when travelling in the dark (Hurst, 1990). These odours are dominated by those of the territorial male. Territory-holders frequently refresh their own marks, as this signals male competitive ability (e.g. Hurst, 1990), and venture into neighbouring territories to 'over-mark' their competitors' urine (Hurst, 1990; Eklund, 1996). In commensal populations urine marks may be deposited so frequently that, mixed with grease and dust, they form 'pillars' many millimetres high (Hurst, 1990; MAFF, 1996; Randall, 1999).

Exactly where this marking occurs, and how tolerant a mouse will be of another mouse's marks, depends on sex, age, social position and location or strategy. Males often tolerate marks from females and juveniles, because female urine contains an aggression-inhibiting factor, while juvenile urine lacks the aggression-eliciting properties of adult male urine (see Smith, 1981). Dominant males produce more than subordinates (Drickamer, 1995), and in captivity, dominant males deposit marks throughout their environment, whereas subordinates tend to pool their urine away from the dominant animal (Desjardins et al., 1973). In general, feral mice over-mark each other's marks less often than do commensals, not least due to the great size of the areas involved, and only selected regions, such as the most favourable nest sites, are strictly defended (Krebs et al., 1995; Crawley, 2000).

Once deposited, urinary marks last for up to 2 days, due to non-volatile major urinary proteins (MUP - e.g. Beynon and Hurst, 2000) which bind the volatile signalling pheromones slowing their release (see Mucignat-Caretta and Caretta, 1999; Hurst et al., 2001). The volatile components in male urine are attractive to both sexes. They stimulate aggression between males and oestrous in females (see Hurst et al., 2001), while MUPs from an unfamiliar male can block pregnancy (Brennan et al., 1999). Laboratory studies have also shown that MUPs are involved in individual recognition, with exposure increasing competitive scent-marking by dominant males (Hurst et al., 2001). Less is known about female MUPs, but they are also thought to be used in individual recognition (e.g. Hurst et al., 2001; but see Cavaggioni and Mucignat-Carreta, 2000).

\subsection{Behaviour within the territory: stable routines in a varying environment}

Mice are primarily crepuscular or nocturnal (e.g. Mackintosh, 1981; Rowe, 1981; Potter, 1994). However, in the absence of predation, the timing of food availability is an important factor (e.g. Dell'Omo et al., 2000), and commensal mice may be active during daylight 
(Surgeoner, 1986; Randall, 1999). Little is known about how much time free-living mice are actually active. Laboratory mice spend less than $50 \%$ of the $24 \mathrm{~h}$ day active (Baumgardner et al., 1980). However, this may be an under-estimate of activity in free-living mice whose environments are far more demanding. During periods of inactivity, mice that are defending territories sleep alone or with their mate, while subordinate animals tend to sleep in groups (Crowcroft, 1966). In captivity, a large proportion of the time budget (17\%) is also spent grooming (Baumgardner et al., 1980). This occurs sporadically during the active periods, and intensively after eating (Brown, 1953; Crawley, 2000). Self-grooming is important for hygiene and insulation (Crawley, 2000), while allo-grooming maintains social relationships (Brain and Benton, 1983; Brown, 1985), and assists the transfer of information about food stuffs (Crawley, 2000).

Commensal individuals are creatures of habit. They travel their entire territory daily, covering (and marking) the same routes repeatedly (e.g. Randall, 1999; Potter, 1994), leading to well-worn runways (Surgeoner, 1986; Potter, 1994; Rentokil, 2001). Through these routines, mice acquire highly habitual responses (e.g. dashes to safety), which they can perform extremely rapidly and with minimal sensory input (Randall, 1999; see also Fentress, 1976, 1977). Thus if an obstacle is removed, mice will often continue to trace a path around it, while if one is placed on a well-used run, an animal travelling at speed may well collide with it (Meehan, 1984; see also Alyan, 1996). However, the degree to which mice rely on such routine-formation varies between individuals and with circumstance. Thus mice selected for low aggression show less use of routines (e.g. Benus et al., 1991; Koolhaas et al., 1999), and feral mice, although covering their home range regularly, traverse different parts on different nights if it is very large (Fitzgerald et al., 1981).

Predictable movement about the range has several functions. It is an essential part of territorial defence, and allows the animal to build up a detailed, continually-updated picture of its domain (e.g. Brown, 1953; Crowcroft, 1966). Continually familiarising themselves with their environment seems to ensure good homing abilities. Mice displaced several hundred metres can navigate back to their nest-site (reviewed Meehan, 1984), and they show evidence of path integration (Alyan, 1996; Alyan and Jander, 1997). Exploration centres on the investigation of olfactory cues related to food and predators, and intra-conspecific communication (Berry, 1970; Lawlor, 1994; Baumans, 1999). Conspecifics' urine, faeces and plantar gland scents are particularly important, revealing age, sexual status, relatedness, and individual identity (Brown, 1985; Lawlor, 1994). Mice may also intensively explore any new or moved objects, novel odours, or disturbed areas (Randall, 1999). Objects that are not marked with familiar urinary odours are clearly very conspicuous to mice, and attract much attention, and eventual marking (Hurst, 1990). Such investigation is done cautiously at first, with typical 'stretched out' risk-assessing postures (e.g. Kemble and Bolwahnn, 1997), and may even prompt avoidance and/or defensive burying (e.g. Misslin and Ropartz, 1981; Londei et al., 1998). However, mice in general seem to investigate novel objects vigorously, and accept them rapidly (Potter, 1994; Randall, 1999).

Foraging is incorporated into these regular patrols (e.g. Crowcroft, 1966). Mice eat up to $20 \%$ of their body weight daily (Berry, 1970; Rowe, 1981; Meehan, 1984). Typically, a mouse consumes about 200 small meals a night, repeatedly visiting approximately 20-30 food sites in the process (see Meehan, 1984; Potter, 1994). Some individuals are more conservative, using a very limited subset of the available food supplies (Dell'Omo et al., 
2000), while others eat at different sites from night to night (Southern, 1954). Food may then be eaten in situ (Meehan, 1984), or carried away to preferred feeding sites (e.g. Crowcroft, 1966). Mice are omnivorous (Baumans, 1999), but they tend to prefer foods high in fat and protein, including meat (Laurie, 1946; Randall, 1999), and can predate live insects (e.g. Landry, 1970). The diet of commensal animals is often determined by the nature of the building they occupy, e.g. grain in grain stores (Henwood, 1995), while that of feral mice includes cereals, grasses, roots, seeds and insect larvae (Whitaker, 1966; Berry, 1970). Mice may retain preferences for foods eaten by their mothers; and also prefer foods eaten by recently-encountered conspecifics (Choleris et al., 1997). However, they readily try new foods (Meehan, 1984; Rentokil, 2001), initially sampling just a bite or two, and returning for more if they experience no ill-effects (Rentokil, 2001). Mice also acquire their daily water requirements from their food, if feeding on a diet with a moisture content of at least 15\% (Fertig and Edmonds, 1969; Meehan, 1984). However, mice will drink if free water is available, and require additional water if living in hot, arid environments, or on a dry or protein-rich diet (Fertig and Edmonds, 1969).

In addition to their regular movements around their own territory, mice also sporadically venture into the territories of neighbouring mice. This they do despite risks of aggression, ready to take advantage should the occupant die, relocate (e.g. Crowcroft, 1966), or alter his boundaries. Thus territorial boundaries can shift as mice jostle for prime sites and extend into recently vacated areas (Crowcroft, 1966; Fitzgerald et al., 1981). Mice also roam beyond their own territorial boundaries when looking for food, in times of shortage (see e.g. Dell'Omo et al., 2000), and for mates.

\subsection{Dominance and territorial aggression}

Fighting is common when mice encounter nomads, or individuals from other demes, especially the first time they meet. Neighbours and strange animals are identified by their salivary and plantar gland scents (Brown, 1985). Males also use saliva and preputial gland odours to assess the 'maleness' and sexual state of potential rivals (Brown, 1985), and are especially aggressive to other males (e.g. Gray et al., 2002). Aggression is also particularly likely in parts of the territory containing important resources like food or nest sites (Gray et al., 2002).

The strictest demarcation of boundaries occurs at high population densities (usually in commensal populations). Males in these populations generally show the most aggression (e.g. Gray and Hurst, 1998; Sluyter and van Oortmerssen, 2000; although see Young et al., 1950), chasing intruders out, biting at their rump and tail (Brain and Parmagiani, 1990). If the intruder is a neighbouring territory-holder, the pursuit lasts to the boundary between the territories, at which point roles reverse and the intruder, now the territory-holder, returns the attack (Crowcroft, 1966). If the intruder is a non-territory-holder, the owner may, in contrast, pursue him well beyond its territory-boundaries, after which the new territory-holder may take up the chase (Crowcroft, 1966). Although the dominant male is usually the most aggressive, all members of a deme will assist in territorial defence (see e.g. Crowcroft, 1966). Intruders unable to escape are likely to face severe injury, even death (Brown, 1953; Crowcroft, 1966; Calaresu, 1979). Non-territory-holders therefore typically alter their behaviour patterns to be active when dominant individuals are asleep, and often nest 
communally with other non-territory-holders or with females and juveniles (Crowcroft, 1966; Mackintosh, 1981).

More tolerant strategies prevail in feral populations and at low population densities (e.g. reviewed van Zeegeren, 1980; Gray and Hurst, 1998). Here, territory-holders initially establish dominance through a series of brief chases, the intruders indicating subordinancy by standing and raising their forepaws and exposing their bellies (Crawley, 2000). Once their subordinancy is established, familiar intruders are either tolerated, or chased less vigorously (Brown, 1953; Gray and Hurst, 1997; Hurst et al., 1997).

This variance in aggression and territorial strategy stems partly from environmental factors determining the availability of resources, and how easy or important they are to defend. Thus feral mice can move from outdoor populations, where the more tolerant strategy predominates, to commensal populations, where clumped resources and high population densities encourage more vigorous marking and aggression (e.g. Proctor, 1994). Conversely, Crowcroft (1966) found that in conditions of extreme cold, dominant mice in an artificial commensal population would huddle peaceably with subordinates that they readily attacked when outside the nest.

However, genetic differences between mice are also influential (e.g. Krackow et al., 2002). Two extremes can be bred from feral mice in the laboratory: aggressive animals, exhibiting short attack latencies (SAL), and less aggressive ones exhibiting long attack latencies (LAL - van Zeegeren, 1980; Benus et al., 1991; Koolhaas et al., 1999). Interestingly, these mice also differ in a number of other behaviours. In particular, SAL mice are more prone to routine-formation, and less able to modulate aggression when presented with a female instead of a male. These researchers therefore suggest that SAL-type mice fare better in stable environments where predictable resources may be defended effectively, whilst a LAL strategy is more adaptive in a changing environment (including perhaps the life of the nomad; see e.g. Mackintosh, 1981), where resources are unpredictable. Whether feral and commensal animals do indeed systematically differ in these traits has yet to be ascertained.

\subsection{Mating and reproduction: mate choice and parental care}

Free-living mice must also find breeding partners and rear litters. In good quality commensal habitats a reproductive female can produce up to 101 (approximately 50 pups) a year (Randall, 1999; Timm, 2000), and thus may spend most of her life engaged in preor post-natal parental care. House mice can be polygamous, with dominant males mating with many females and vice versa (Patris and Baudoin, 1998; Wright and Brown, 2000). However, some pairs form bonds that last the whole season (see Berry, 1970). Little is yet known about the factors underlying mate fidelity, nor whether individuals actively search for a partner, or find them by chance during exploration. Breeding is, however, known to be year-round in commensal populations, and more seasonal in wild populations. For example Berry (1968) found that breeding in a wild English population occurred between April and September. The cessation of breeding during the winter seems due to reduced food and nesting material availability rather than cold (Laurie, 1946; Randall, 1999). Thus mice in Australian wheat-field populations breed only during months when food and cover are readily available (Pelikán, 1981; Pech et al., 1999), and the same seems to apply to sub-Antarctic populations which breed only during long summer days (Pye, 1993). 
To reproduce, females need to be in good physical condition (Meehan, 1984), unsuppressed by other females, and exposed to two volatile components from male urine, a brevicomin and a thiazole bound to the MUPs (Brown, 1985; Beynon and Hurst, 2000). These mediate the Whitten effect, whereby male odour brings females into oestrous (reviewed Meehan, 1984; Baumans, 1999). The oestrous cycle lasts between 4 and 6 days (Berry, 1970), and males assess whether a female is receptive by her vaginal odours (Brown, 1985). Females also exhibit post-partum oestrus in the $24 \mathrm{~h}$ following the birth of a litter (Baumans, 1999).

Females may mate with a number of males during a single oestrous, and seem attracted to unfamiliar males (Patris and Baudoin, 1998; Wright and Brown, 2000). Sexually receptive females assess 'maleness' by preputial odour (Scott and Pfaff, 1970; Brown, 1985), and use other cues to assess other attributes. They also use urinary odour cues to discriminate against males of the same major histocompatibility complex (Jordan and Bruford, 1998), thereby tending to avoid inbreeding (see Eklund, 1996) - although in a deme, females may still mate with their own fathers (van Zeegeren, 1980). Females also generally avoid males carrying the gene for brachyury, a potentially lethal short-tailed condition (Boyse, 1983; Lenington and Egid, 1985; Lenington et al., 1992), and prefer unparasitised males, or males with a high parasite resistance (Lenington et al., 1992; Patris and Baudoin, 1998; Ehman and Scott, 2001), which they may assess through urinary cues (Ehman and Scott, 2001). They may also choose males by their rate of ultrasonic calling, which positively correlates with social status (see laboratory studies cited by Warburton et al., 1989). The strong over-marking that dominant males apply to females' urine marks also means that they are probably well aware of the dominance status of any familiar male through their odours (Hurst, 1990). Females generally do not attack a male intruder that has defeated her mate, and/or can dominate her physically, and will often mate with him even if she has a current litter that he is likely to kill (Parmagiani et al., 1989). Thus females exhibit mate choice, and will refuse some males altogether (Patris and Baudoin, 1998). By doing so, females influence their offspring's later success. In laboratory conditions, females allowed to mate with a preferred male produce more litters, and pups with enhanced performance in dominance contests and nest-building, than those mated with non-preferred males (Drickamer et al., 2000).

Males also seem to display some mate preference; for example, preferring unfamiliar females to familiar females (Hayashi and Kimura, 1983 cited by Meehan, 1984; see also Shah et al., in press cited by Fleming et al., 2002). Males also seem to prefer feminized females, with shorter anogenital distances (Palanza et al., 1995; Drickamer, 1996), which can be assessed through odour cues (Drickamer et al., 2001).

Once two mice have identified each other as suitable partners, the female indicates sexual motivation through hopping, darting movements and ear-wiggling (Crawley, 2000). The male then approaches and investigates, paying particular attention to her genital odours (Brown, 1985; Crawley, 2000). Both animals, especially the male, produce ultrasonic courtship calls (Smith, 1981; Meehan, 1984). The male then mounts from the rear, grasping the female's flanks with his front paws. If the male is subordinate, he may stop if a more dominant male approaches (Brown, 1953; see also Damato and Pavone, 1992). Following copulation, the male grooms his genitals, and shows little attention to the female (Crawley, 2000). Implantation occurs 5 days after fertilisation, but can be delayed up to 12 days in lactating females (Berry, 1970), and foetal resorption may occur if a strange but dominant 
male intrudes into the territory, the so-called Bruce effect (Hafer, 1990; Brennan et al., 1999).

Gestation lasts between 18 and 21 days (Berry, 1970; Baumans, 1999), and during the final 3 days the female begins to construct her nest (Brown, 1953). Reproductive females are highly motivated to nest-build, so much so that a ball of cotton wool makes an effective bait for traps (Randall, 1999). Pregnant females build particularly complex nests (reviewed Meehan, 1984), and in conditions where nest-building is undisturbed, the nests will be spherical or a deep bowl-shape. Females in cold climates make the most complex nests, especially those with previous breeding experience (Wolfe and Barnett, 1977 cited by Meehan, 1984). A good nest can be extremely effective, significantly increasing litter survival (Southwick, 1955 cited by Mackintosh, 1981). Even at outside temperatures of $-3{ }^{\circ} \mathrm{C}$ it can be more than $17^{\circ} \mathrm{C}$ within the nest (Barnett et al., 1975 cited by Meehan, 1984).

Unfortunately for a pregnant female, her activities may stimulate other females to perform nesting behaviour, resulting in damage to her nest as other females attempt to use the material (Brown, 1953). However, females often become intensely aggressive towards non-reproductive individuals during the final days of pregnancy (e.g. Vom Saal et al., 1995), and will vigorously protect their nests, biting intruders' heads and bellies (Brain and Parmagiani, 1990). This increased aggression may function to allow the female to defend her nest and pups (see Mandillo and D'Amato, 1997), or even be a means of assessing the dominance status of any intruding males. Although females can defend their nest against small numbers of conspecifics, nest-defence can become impossible if the female must repel large numbers (Brown, 1953; Crowcroft, 1966), and nest disturbance shortly before or after the birth of the litter increases the chances of infanticide by the female (Brown, 1953; see Crowcroft, 1966). Nest-defence can also be influenced by whether a female experienced stressors during gestation, although reported effects are somewhat contradictory. Pardon et al. (2000) reported stressed females to be impaired at nest defence because of their tendency to exhibit withdrawal behaviours, but Kinsley and Svare (1988) and Meek et al. (2001) reported them to be more aggressive.

Pups are usually born at night, and if the female is not disturbed, she will spend the time between each birth cleaning them (Berry, 1970; Pelikán, 1981). If disturbed, females become more active, and may even leave the nest between deliveries (Brown, 1953). A female's litter size is usually positively correlated with her bodyweight (Berry, 1970). Furthermore, the first litter of the season tends to be smaller, with the second and third litters being the largest, followed by a decline in size in any subsequent litters (Berry, 1970; Pelikán, 1981). Pup losses, both pre- and post-natally, have been argued to be adaptive, allowing the mother to wean the maximum number of healthy pups in a range of environmental conditions (reviewed Krackow, 1993).

Reproductive females find pup odour and calls attractive and reinforcing (Meek et al., 2001). These cues also elicit specific forms of maternal care, with 'wriggling calls' eliciting nest-building and maternal licking (Crawley, 2000), and the brief and higher frequency ultrasonic vocalisations of cold pups eliciting retrieval (Smith, 1981; Roberts, 1998) and nest maintenance, (Noirot, 1974). Differences in the characteristics of these various calls may also mediate the mother's changes in maternal behaviour with pup age and sex (Benus and Henkelmann, 1998; Hahn et al., 1998). Male-skewed litters, for example, receive more 
licking and grooming (Alleva et al., 1989; Laviola and Terranova, 1998). The quality and quantity of the female's maternal behaviour is also affected by her genotype (Mendl and Paul, 1991a; Benus and Rondigs, 1996), and by her levels of stress, which tends to reduce pup-licking (Braastad, 1998; Meek et al., 2001).

When the pups reach 10 days of age, maternal care begins to include bringing solid food back to the nest from foraging trips (Mays, 1999; Horn, 2000), and at around 2 weeks, the mother's aggression to other adults begins to subside (Mackintosh, 1981). As the pups reach 3-4 weeks of age, the female then begins to accompany the young on their first excursions from the nest (e.g. Crowcroft, 1966). Throughout this maternal period, however, mothers may destroy their own litters, with causal explanations including disturbance, overcrowding and food-restriction, and functional or evolutionary explanations including optimising litter size to the available resources (see Krackow, 1989; Elwood, 1991; Palanza et al., 1996).

Issues of nest defence and the potential for infanticide might lead us to expect that reproductive females always nest alone, or only with their mates, but females in some populations nest, and even nurse, communally (e.g. Young et al., 1950; König, 1993; Hayes, 2000). Communal nursing often occurs because females are unable to distinguish their pups from those of other mothers, particularly when litters are born within a few days of each other (e.g. Manning et al., 1995; but see Chantrey and Jenkins, 1982). However, studies of communal nursing in semi-natural and laboratory populations show that it can actually be beneficial. Communally nursing females, especially sisters, exhibit a greater lifetime reproductive success, and their pups exhibit increased growth rates and weaning weights (König, 1994; Manning et al., 1995; although see Smith, 1981). There remains debate as to whether communal rearing is an adaptive strategy even in optimal habitats, or a response to ecological constraints such as limited resource availability (e.g. insufficient nesting sites or material), or factors which make solitary-rearing too costly, such as low temperatures or high costs of repelling infanticidal conspecifics in crowded conditions (reviewed Hayes, 2000).

The reproductive male may also attend to his pups. Like the mother, he may clean them, retrieve them if they climb out of the nest, defend them against attack, and escort them during early exploratory forays (Crowcroft, 1966; Patris and Baudoin, 2000; see also Wright and Brown, 2000). However, some males leave all parental responsibilities to their mates (Jakubowski and Terkel 1982 cited by Meehan, 1984). This may occur when males and females live together in large groups in which males seek to maximise matings (see Wright and Brown, 2000).

Adult males can be highly infanticidal, but even those that do not show paternal care are predisposed not to destroy their own young. Mated males exhibit notably less infanticidal tendencies, even before the birth of the litter (Lonstein and De Vries, 2000). Laboratory studies have shown that some males simply become less infanticidal at the time when the pups are born, some are less infanticidal if copulation is followed by cohabitation with the female (Perrigo et al., 1992, 1993), and some are less infanticidal if they live with a pregnant female or if the litter is born in the male's home cage (Lonstein and De Vries, 2000). Thus male mice seem to maximise their reproductive success by becoming non-infanticidal or even parentally responsive in situations where they are likely to encounter their own pups (Elwood and Mason, 1994). However, adult males are highly likely to kill pups sired by another male (e.g. Elwood and Mason, 1994). Thus if they encounter an unfamiliar female, 
e.g. by intruding into her territory, they are likely to kill her pups. Infanticide is said to be most common in males that are both intruding and dominant (see Parmagiani et al., 1989; Perrigo et al., 1993). Males that successfully subordinate a lactating female are particularly likely to be pup-killers, presumably because they have the greatest chance of siring a new and successful litter when the female comes into oestrous (Parmagiani et al., 1989).

The birth of a litter similarly elicits a range of behaviours from other adults and sub-adults. Adult females can also be pup-killers (e.g. Lonstein and De Vries, 2000). Indeed, the most infanticidal gender varies between studies, as if there are population differences in how adaptive this behaviour is for males versus females (Parmagiani et al., 1989). Thus while some female conspecifics help care for the pups and even suckle them, others may be dangerous. Such variance presumably reflects the balance of gains to inclusive fitness by helping a younger sib or niece/nephew, versus the potential gains in resources (e.g. nest-sites) reaped by killing the litter. However, the effects of resource availability and relatedness on infanticide versus allo-parenting by females has been little studied.

\subsection{Morbidity and mortality: death and illness in natural conditions}

Mice, especially feral animals, are preyed upon by owls, weasels, cats, and other predators (Elton, 1942; Berry, 1970; Berry and Bronson, 1992)-although rats seem not to be a normal predator (Meehan, 1984). The impact of predation on overall population mortality rates is, however, generally insignificant (Berry and Bronson, 1992). Overtly pathological conditions are also relatively rare as a cause of death (Berry, 1970), but include pneumonia, mouse parvovirus and Bacillus and Streptococcus infections (Elton, 1942; DeLong, 1967; Pech et al., 1999). However, as we have seen, fatalities through fighting are a major risk in commensal populations (e.g. Crowcroft, 1966). Winter is the most serious threat to feral mice, since winter months generally produce a chronic shortage of their major food items, resulting in starvation and hypothermia (see Berry, 1970; Berry and Bronson, 1992). In fact, a particularly harsh winter may kill $95 \%$ of a wild population (Berry and Bronson, 1992).

Therefore, the average lifespan of the free-living house mouse is often much less than its potential maximum of 2 years (Berry, 1970). In one feral population, the average lifespan was estimated as low as 3 months (Berry and Jakobson, 1971), while some put the mean for commensal animals at 9-12 months (Timm, 2000). Longevity is also affected by sex (females living longer than males; Stickel 1979 cited by Meehan, 1984), and birth date (the earlier a mouse is born in the breeding season, the greater its likely life span; see Berry, 1970). Overall, the high mortality rates of adult house mice help explain this species' evolved strategy of early maturation and high reproductive rates (see e.g. Ricklefs, 1999).

\section{Discussion and implications for mouse-use in the laboratory}

So how does how understanding mouse behavioural biology help inform its husbandry and use in research? This review shows the extensive differences in the physical, social and sensory environments of wild and laboratory mice. Here, then, we consider the impact of these differences on four topics - (i) housing issues that may affect welfare; (ii) housing issues that may affect mouse functioning; (iii) factors that could refine behavioural tests; 
and finally, (iv) long-term housing/husbandry effects that may lead to unexplained variance in research results.

\subsection{Mouse behavioural biology and welfare in the laboratory}

Several features of mouse biology explain the species' success and long relationship with humans. In breeding units and research laboratories this highly adaptable, opportunistic and rapidly-breeding species has seemingly thrived (e.g. Beilharz, 1994). However, the stereotypies and barbering (whisker-plucking) prevalent in some mice (e.g. Nevison et al., 1999a; Sarna et al., 2000) do raise welfare concerns, as do the poor breeding performance and high sensitivity to environmental change seen in some strains (e.g. A/Sn; A. Peters, personal communication). Examining the differences between captive and free-living lifestyles can help generate new hypotheses about how welfare problems arise.

To date only certain issues have been considered, and even fewer investigated fully. Nesting material and flooring substrates have been well studied (reviewed Olsson and Dahlborn, 2002); weaning age has received some attention (Würbel and Stauffacher, 1997, 1998); and some effects of cage size and enrichments have been researched (e.g. McGregor and Ayling, 1990; Nevison et al., 1999b; van Loo et al., 2001). Olsson et al. (2003) raise questions about the welfare impact of the lack of UV-wavelengths in indoor lighting; the effects of inbreeding on odour-based individual recognition; the lack of opportunities to burrow; and regular, scent-disruptive cage cleaning.

Our review confirms the likelihood of all these issues as potential causes of poor welfare, but also prompts a number of new hypotheses. Many social factors, for example, might decrease welfare. These include having no choice in dispersal age or strategy, and being exposed to auditory and olfactory cues from mothers following 'weaning', yet with direct contact impossible. Mice may find it aversive to be housed with unfamiliar, same-sex adults, and laboratory housing provides little opportunity for escape from aggressive encounters, or the odours and vocalisations of potentially threatening conspecifics. Finally, welfare may be reduced through the inability to choose mates or parental strategy. Thus understanding the lifestyle of free-living mice generates new ideas for research that could improve welfare in research establishments.

\subsection{Mouse behavioural biology and normalcy in the laboratory}

Stereotypy and barbering do not just raise welfare issues. Stereotypy has been linked to dysfunction of the brain regions controlling the initiation and inhibition of behaviour (e.g. Dantzer, 1991; Lewis et al., 1996; Garner and Mason, 2002), and barbering may be linked with obsessive compulsive disorder (OCD-Garner, in preparation). The recipients of barbering are also likely to be abnormal, as whisker-trimming can greatly alter the function and anatomy of the barrel cortex, ability to discriminate between textures, and 'whisking' patterns (Carvell and Simons, 1996; Kossut, 1998; Cybulska-Klosowicz and Kossut, 2000). The causal factors of these behaviours are only just starting to be elucidated, and include weaning earlier than is natural (Würbel and Stauffacher, 1997, 1998), the inability to escape from intra-specific aggression (Nevison et al., 1999b), and also possibly unnatural lighting conditions (Garner, in preparation). However, the potential 
roles of the many other differences between free-living and cage life have not yet been investigated.

Physiological and anatomical measures of brain structure and function show the potential impact of housing laboratory mice in barren, unstimulating environments. Studies of laboratory rodents, including mice, have shown that increasing environmental complexity and/or providing opportunities to move under cover can increase brain weight and alter the relative weights of different brain structures (e.g. Katz and Davies, 1984; Kempermann et al., 1997), and increase neural connectivity and neurogenesis (van Praag et al., 1999a,b; Nakamura et al., 1999). Environmental 'enrichment' can also result in neurochemical changes (see Renner and Rosenzweig, 1987), delay the onset of degenerative diseases such as Huntington's Disease (van Dellen et al., 2000; Hockley et al., 2002), improve visual acuity (Prusky et al., 2000); and alter performance in behavioural tasks such as open field activity and food-seeking behaviours (Henderson, 1970; Manosevitz, 1970; Warren et al., 1982). The key enrichment properties needed for these various effects to occur, and the importance of the many other differences between free-living and laboratory lifestyles, have not been fully investigated. However, overall we can see that the great differences between natural and laboratory environments potentially have a major impact on the normalcy of brain and behavioural functioning, with likely implications for the use of mice as models in, for instance, some areas of neuroscience (see also Würbel, 2001 for further discussion).

\subsection{Mouse biology and the behavioural tests used in research}

Test batteries like the 'SHIRPA' protocol are used to assess the characteristics of research mice and the phenotypic variation caused by genetic modification (e.g. Rogers et al., 1997, Nolan et al., 2000; see also Crawley, 2000). Understanding mouse behavioural biology can potentially help improve both the replicability of such behavioural tests (by refining how they are conducted), and also their sensitivity (by suggesting new, more ethological protocols).

As we have seen, murine senses are enormously different from our own; their social and territorial behaviours, and their needs to avoid predation, give them very different priorities from ours; and they have ultradian and circadian activity cycles that we may not pay heed to. For instance, time of testing can affect the measured nociception of mice (Chesler et al., 2002), while rats exhibit less escape behaviour and appear to be 'less stressed' in a forced swimming paradigm if tested during the dark period (Kelliher et al., 2000). Some suggest that research results may differ, too, depending on whether animals are tested after a quiet weekend, or at the end of a noisy week (Milligan et al., 1993). Different human experimenters can also have a significant effect on the results of mouse nociception tests, possibly as a result of handling style (Chesler et al., 2002): and it is easy to imagine how significant this must be for this small, touch-sensitive, naturally-predated animal. However, other sensory cues may well be important; perhaps glasses-wearers provide more predator-like visual stimuli, and vegetarians, a less predator-like odour? Alternatively, experimenters may become differentially associated (perhaps via their odours) with aversive test procedures, leading to conditioned responses of varying magnitudes (see Davis and Balfour, 1992). Other possible sensory issues in test environments include computers or monitors, 
which produce potentially aversive ultrasounds (Sales et al., 1999), and the presence of any horizontal eye-like spots (e.g. infra-red LEDs and photocell detectors), or large dark objects, which again may be perceived as predator cues (Gerlai, 2001).

Additional factors affecting mouse stress, fear or exploratory motivations are also potential confounds. For instance, the last mice removed from a cage for testing show greater nociceptive sensitivity than the first-removed animals (Chesler et al., 2002), while mouse responses to apomorphine differ when tested in the homecage from when tested in a novel box (Harkin et al., 2000). The tendency of mice to be fearful in a novel place yet then to habituate rapidly, can also lead to experimental 'order effects' unless controlled for (for an illustration of this see Gerlai, 2001). Gerlai and Clayton (1999) and Gerlai (2001) suggest that some apparent strain differences in spatial memory are actually strain differences in stress sensitivity, revealed in fear-inducing tests, and with knock-on effects on hippocampal function (see also Bilbo and Nelson, 2001); while strain differences in response to amphetamine can be dramatically affected by pre-test food-restriction (Cabib et al., 2000). Finally, when considering exploratory behaviour, Gerlai and Clayton (1999) suggest that hunger, and breeding and dominance status may affect how willing mice are to locomote in tests such as the Open Field.

Understanding mouse behavioural biology can further aid research by suggesting additional data to help interpret findings. To give a hypothetical example, the Elevated Plus Maze is generally used to assess anxiety, but its use could perhaps be refined by assessing other traits likely to affect how mice behave in the apparatus, such as ability to assess vertical drops (e.g. due to visual acuity, or even perhaps echo-location) and reliance on thigmotaxis. Likewise, studies finding treatment (e.g. knock-out) effects on mouse maternal behaviour (e.g. Brown et al., 1996; Alston-Mills et al., 1999) could probably be aided by more knowledge of the factors affecting natural nest-building, maternal defensive aggression, infanticide, differential responsiveness to various pup cues, and the factors involved in allo-parental care. Novel ethologically-relevant tests can also be extremely valuable. Olsson et al. (2003) and Gerlai and Clayton (1999) discuss how test stimuli should be suited to the mouse's sensory biases, and Birrell and Brown (2000) provide a nice example of this in rats, using olfactory and tactile stimuli as cues in a naturalistic task: digging for food. Deacon and co-workers (Deacon et al., 2001; Guenther et al., 2001; Cunningham et al., 2003) harnessed mouse digging and nesting in studies of prion disease, finding that reductions in these behaviours proved far more sensitive assays of disease onset than more traditional techniques like the scoring of clinical signs.

\subsection{Mouse behavioural biology and inter-laboratory variation}

It has long been known that housing and test conditions can affect the research data generated by mice (see Bilbo and Nelson, 2001 and Würbel, 2001). Recently, however, even sites providing very similar housing conditions have been found to vary in some test results. For example, mice from the same strain and supplier vary in their nociceptive sensitivity if housed in different units (Chesler et al., 2002). Such findings can be particularly challenging for research when unexplained gene $\times$ environment interactions occur. Crabbe et al. (1999) and Wahlsten et al. (2003) assessed the behaviour of mice from various strains in three apparently identical laboratories, using tests such as rotarod balance and elevated 
plus maze behaviour. Although all aspects of husbandry and testing were kept as similar as possible they found that the magnitude and direction of some strain differences varied from lab to lab. These studies demonstrate how units can appear to be identical to humans, yet are evidently far from identical to mice. Understanding mouse behavioural biology has enormous potential for pin-pointing where such effects really come from.

One likely candidate is sensory differences between mouse units which are subtle or undetectable for us, but important for mice. For example, Olsson et al. (2003) vividly describe how rodent vocalizations may, to mice, resemble the noise levels of 'humans ... in a crowded room with everyone shouting to each other'. Since much mouse vocalisation occurs in the ultrasonic, differences in true vocalisation level are unlikely to be detected by humans, and the extent to which such vocalisations affect the inhabitants of any one cage will depend on the age-, sex- and strain-structure of the colony, as well as the frequency and severity of any stressors conspecifics are exposed to. Numerous other uncontrolled, unassessed sources of sounds exist in the laboratory too, e.g. fluorescent tubes, (some of which produce ultrasound-G. Mason, pers. obs.), technicians, radios and cleaning equipment (some of which produce noise levels of up to $75 \mathrm{~dB}$-Milligan et al., 1993; Sales et al., 1999). Such levels differ between working and non-working hours, and may well differ between units (e.g. Clough, 1982; Milligan et al., 1993; Sales et al., 1999).

Olfaction is another obvious potential influence. Social odours can have profound effects on mouse development and behaviour, and they could also potentially influence the social density which mice perceive themselves housed at, perhaps even their stress levels. Furthermore, exposure to such social odours could well differ between sites, due to the size, ageand sex-structure, airflow, and layout of each colony, the number and types of strain within it, and perhaps even the animals' stress levels. Non-social odours may also be important. For example, strong odours can induce defensive behaviours such as immobility and burrowing (Kemble and Bolwahnn, 1997), suggesting that they may be aversive. If human or cage-cleaning products are aversive, and differentially so between labs, this may well also affect mouse behaviour within a given unit.

The visual environment is also little-standardised across units. Different 'white' lights emit varying spectra (see e.g. Aphalo, 2001). Thus lighting that appears similarly white to us may vary in colour, hue and brightness to mice (see e.g. Hoffman et al., 1985). Units differ greatly in their light levels during the dark phase, some being dimly illuminated by fire safety lights, while others are completely (and very unnaturally) dark. Furthermore, cage and rack design affects within-cage illuminance levels (e.g. Clough, 1982). Although the impact of these subtle differences has not been investigated, wide variation in lighting has long been known to be important for rodents: illuminance levels influence retinal atrophy rates (Clough, 1982); activity and behaviour in several mouse strains (e.g. Ross et al., 1966); and possibly the prevalence and severity of barbering (Garner, in preparation). Mice caged at the top of a rack have greater 'emotionality', and an enhanced likelihood of developing diabetes in females in a mouse model of this disease (Ader et al., 1991). Finally, within-cage lighting levels can influence the quality of maternal behaviour and pup mortality (Clough, 1982).

Subtle aspects of husbandry may also differ between units. For instance, cage-cleaning causes mice acute and potentially long-term stress (e.g. Saibaba et al., 1996), presumably due to the handling and scent-disruption involved. Cleaning products may vary between 
units, and so too may subtle aspects of the process such as the degree to which it disturbs mice in the resting phases of their diurnal rhythms. For breeding females, other key husbandry effects might include the suitability and timing of nest-material provision; social grouping (e.g. whether they are housed with their breeding partner, or other breeding or non-breeding females); and the proximity of recently-weaned pups.

Although not directly relevant to studies like that of Crabbe and colleagues, these last effects warrant attention because of the developmental plasticity of mice and the profound effects of early experience on adult characteristics. There may be numerous subtle differences in housing and husbandry that cause differences in maternal stress level, and pup growth rate and developmental stage when removed from the mother, and these may yield offspring that differ in phenotype, despite identical genetic backgrounds.

Thus understanding mouse behavioural biology should provide the key to unravelling why mouse units sometimes yield different research results, even when mouse genotype is controlled and husbandry and testing apparently standardised. Manipulating such variables, such as exposure to neighbour odours, or to ambient ultrasounds, may even prove a useful way of experimentally investigating gene $\times$ environment interactions in the future.

\section{Conclusions}

Overall, we hope that this review has provided a greater understanding of how free-living mice interact with their world, and illustrated how understanding natural history is important for those working with laboratory mice. As we have seen, mice are a remarkably adaptable species, but despite this ability to adapt, their welfare and normalcy may well be compromised in laboratory units, their natural behavioural biology suggesting many diverse reasons for this. We have also shown how different their sensory worlds are from ours; for example, by showing how powerfully odour cues affect behaviour and development, and this may affect their behaviour as research animals. Lastly we have shown that their fascinating developmental plasticity could help account for some differences in phenotype between testing facilities.

\section{Acknowledgements}

Naomi Latham is funded by UFAW. Georgia Mason is funded by the BBSRC. We are very grateful to Manuel Berdoy, Chris Sherwin, Tina Widowski and Hanno Würbel for their constructive comments on this manuscript.

\section{References}

Ader, D., Bennett Johnson, S., Huang, S., Riley, W., 1991. Group size, cage shelf level, and emotionality in non-obese diabetic mice: impact on onset and incidence of IDDM. Psychosom. Med. 53, 313-321.

Alleva, E., Caprioli, A., Laviola, G., 1989. Litter gender composition affects maternal-behavior of the primiparous mouse dam (Mus musculus). J. Comp. Psychol. 103, 83-87.

Alston-Mills, B., Parker, A., Eisen, E., Wilson, R., Fletcher, S., 1999. Factors influencing maternal behavior in the hubb/hubb mutant mouse. Physiol. Behav. 68, 3-8. 
Alyan, S., 1996. Evidence for resetting the directional component of path intgration in the house mouse (Mus musculus). Ethology 102, 629-638.

Alyan, S., Jander, R., 1994. Short-range homing in the house mouse, Mus musculus: stages in the learning of directions. Anim. Behav. 48, 285-298.

Alyan, S., Jander, R., 1997. Interplay of directional navigation mechanisms as a function of near-goal distance: experiments with the house mouse. Behav. Proc. 41, 245-255.

Aphalo, P., 2001. Lamp emission spectra. Website: http://www.cc.joensuu.fi/photobio/lamps.html.

Baker, R., 1946. A study of rodent populations on Guam, Mariana Islands. Ecol. Monogr. 16, 393-408.

Barnard, C., Behnke, J., Gage, A., Brown, H., Smithurst, P., 1998. Maternal effects on the development of social rank and immunity trade-offs in male laboratory mice (Mus musculus). Proc. R. Soc. Lond. B 265, 2087-2093.

Barnett, S., Burn, J., 1967. Early stimulation and maternal behavior. Nature 213, 150-152.

Baumans, V., 1999. The laboratory mouse. In: Poole, T. (Ed.), The UFAW Handbook on the Care and Management of Laboratory Animals. Blackwell, London.

Baumgardner, D., Ward, S., Dewsbury, D., 1980. Diurnal patterning of eight activities in 14 species of muroid rodent. Anim. Learn. Behav. 8, 322-330.

Beilharz, R., 1994. Does the notion of environmental enrichment assist animal well-being? in: Proceedings of the ANZCCART Conference. Glen Osmond, Sydney, Australia, October 1993.

Benus, R., Bohus, B., Koolhaas, J., van Oortmerssen, G., 1991. Heritable variation for aggression as a reflection of individual coping strategies. Experientia 47, 1008-1019.

Benus, R., Henkelmann, C., 1998. Litter composition influences the development of aggression and behavioural strategy in male Mus domesticus. Behaviour 135, 129-1249.

Benus, R., Rondigs, M., 1996. Patterns of maternal effort in mouse lines bidirectionally selected for aggression. Anim. Behav. 51, 67-75.

Berry, R., 1968. The ecology of an island population of the house mouse. J. Anim. Ecol. 37, 445-470.

Berry, R., 1970. The natural history of the house mouse. Field Studies 3, 219-262.

Berry, R., Bronson, F., 1992. Life history and bioeconomy of the house mouse. Biol. Rev. 67, 519-550.

Berry, R., Jakobson, M., 1971. Life and death in an island population of the house mouse. Exp. Gerontol. 6 , 187-197.

Berry, R., Jakobson, M., 1974. Vagility in an island population of the house mouse. J. Zool. 173, 341-354.

Besselsen, D., 1997. Biology of Laboratory Rodents. Website: http://www.ahsc.arizona.edu/uac/notes/classes/ rodentbio/rodentbio.html.

Beynon, R., Hurst, J., 2000. Making sense (and diagnostic use) of scents. Business: The quarterly magazine of the Biotechnology and Biological Sciences Research Council.

Bilbo, S., Nelson, R., 2001. Behavioural phenotyping of transgenic and knockout animals: a cautionary tale. Lab. Anim. Europe 1, 16-26.

Birrell, J., Brown, V., 2000. Medial frontal cortex mediates perceptual attentional set shifting in the rat. J. Neurosci. $20,4320-4324$.

Bourne, J., 1997. Mice and their control, Alberta agriculture, food and rural development. Website: http://www. agric.gov.ab.ca/agdex/600/8300000.html.

Boyse, E., 1983. Some behavioural consequences of H2:Qa:Tla polymorphism. Cell. Immunol. 82, 33-35.

Braastad, B., 1998. Effects of prenatal stress on behaviour of offspring of laboratory and farmed mammals. Appl. Anim. Behav. Sci. 61, 159-180.

Brain, P., 1992. Understanding the behaviours of feral species may facilitate design of optimal living conditions for laboratory rodents. Anim. Tech. 43, 99-105.

Brain, P., Benton, D., 1983. Conditions of housing, hormones and aggressive behavior. In: Svare, B. (Ed.), Hormones and Aggressive Behavior. Plenum Press, New York, pp. 349-372.

Brain, P., Parmagiani, S., 1990. Variation in aggressiveness in house mouse populations. Biol. J. Linn. Soc. 41, 257-269.

Brennan, P., Schellinck, H., Keverne, E., 1999. Patterns of expression of the immediate-early gene egr-1 in the accessory olfactory bulb of female mice exposed to pheromonal constituents of male urine. Neuroscience 90 , 1463-1470.

Bronson, F., 1979. The reproductive ecology of the house mouse. Q. Rev. Biol. 54, 265-299.

Brown, R., 1953. Social behavior, reproduction and population changes in the house mouse (Mus musculus L.). Ecol. Monogr. 23, 217-240. 
Brown, R., 1985. The rodents II: suborder myomorpha. In: Brown, R., Macdonald, D. (Eds.), Social Odours in Mammals. Clarendon Press, Oxford.

Brown, J., Ye, H., Bronson, R., Dikkes, P., Greenberg, M., 1996. A defect in nurturing in mice lacking the immediate early gene fosB. Cell 86, 297-309.

Cabib, S., Orsini, C., Le Moal, M., Piazza, P., 2000. Abolition and reversal of strain differences in behavioural responses to drugs of abuse after brief experience. Science 289, 463-465.

Calaresu, G., 1979. Effects of early experience and status on social interactions of male wild house mice Mus musculus L. Mouse News 4, 25-26.

Calderone, J., Jacobs, G., 1995. Regional variations in the relative sensitivity to UV-light in the mouse retina. Vis. Neurosci. 12, 463-468.

Carvell, G., Simons, D., 1996. Abnormal tactile experience early in life disrupts active touch. J. Neurosci. 16, 2750-2757.

Cavaggioni, A., Mucignat-Carreta, C., 2000. Major urinary proteins, alpha(2u)-globulins and aphrodisin. Biochim. Biophys. Acta 1482, 218-228.

Chambers, 1., Singleton, G., Krebs, C., 2000. Movements and social organisation of wild house mice (Mus domesticus) in the wheatlands of northwestern Australia. J. Mammal. 81, 59-69.

Chantrey, D., Jenkins, B., 1982. Sensory processes in the discrimination of pups by female mice (Mus musculus). Anim. Behav. 30, 881-885.

Chapillon, P., 1999. Very brief exposure to visual distal cues is sufficient for young mice to navigate in the Morris water maze. Behav. Proc. 46, 15-24.

Chesler, E., Wilson, S., Lariviere, W., Rodriguez-Zas, S., Mogil, J., 2002. Identification and ranking of genetic and laboratory environment factors influencing a behavioural trait, thermal nociception, via computational analysis of a large data archive. Neurosci. Biobehav. Rev. 26, 907-923.

Choleris, E., Guo, C., Liu, H., Mainardi, M., Valsecchi, P., 1997. The effect of demonstrator age and number on duration of socially induced food preferences in house mouse (Mus domesticus). Behav. Proc. 41, 69-77.

Church, S., Bennett, A., Cuthill, I., Hunt, S., Hart, N., Partridge, J., 1998. Does Lepidopteran larval crypsis extend into the ultraviolet? Naturwissenschaften $85,189-192$.

Cirulli, F., 2001. Role of environmental factors on brain development and nerve growth factor expression. Physiol. Behav. 73, 321-330.

Clough, G., 1982. Environmental effects on animals used in biomedical research. Biol. Rev. 57, 487-523.

Cowley, J., Pewtress, R., McDonald, S., 1990. Exposure early in life to urine from mice with translocation chromosomes and isolated mice has long term effects on development and behaviour. In: Macdonald, D., Müller-Scharze, D., Natynczuk, S. (Eds.), Chemical Signal in Vertebrates 5. Oxford University Press, Oxford, pp. 260-270.

Crabbe, J., Wahlsten, D., Dudek, B., 1999. Genetics of mouse behavior: interactions with laboratory environment. Science 284, 1670-1672.

Crawley, J., 2000. What's Wrong with my Mouse? Behavioural Phenotyping of Transgenic and Knockout Mice. Wiley, Chichester.

Crowcroft, P., 1966. Mice All Over. Foulis, London.

Cunningham, C., Deacon, R., Wells, H., Boche, D., Waters, S., Diniz, C., Scott, H., Rawlins, J., Perry, V., 2003. Synaptic changes characterize early behavioural signs in the ME7 model of murine prion disease. Eur. J. Neurosci. 17, 2147-2155.

Cybulska-Klosowicz, A., Kossut, M., 2000. Roughness discrimination with vibrissae depends on function activation of barrel cortex in mice. Eur. J. Neurosci. 12 (Suppl.), 430.

Damato, F., Pavone, F., 1992. Role of anxiety in subordinate male mice sexual behavior. Pharmacol. Biochem. Behav. 43, 181-185.

Dantzer, R., 1991. Stress, stereotypies and welfare. Behav. Proc. 25, 95-102.

Davis, H., Balfour, D. (Eds.), 1992. The Inevitable Bond: Examining Scientist-Animal Interactions. Cambridge University Press, Cambridge.

Dawkins, M., 1980. Animal Suffering: the Science of Animal Welfare. Chapman and Hall, London.

Deacon, R., Raley, J., Perry, V., Rawlins, J., 2001. Burrowing into prion disease. NeuroReport 12, $2053-2057$.

Dell'Omo, G., Ricceri, L., Wolfer, D., Poletaeva, I., Lipp, H., 2000. Temporal and spatial adaptation to food restriction in mice under naturalistic conditions. Behav. Brain Res. 115, 1-8.

DellPest, 2001. Rodent Control. Website: http://www.galaxymall.com/services/pestcontrol/rodent.html. 
DeLong, K., 1967. Population ecology of feral house mice. Ecology 48, 611-634.

Desjardins, C., Maruniak, J., Bronson, F., 1973. Social rank in house mice: differentiation revealed by ultraviolet visualization of urinary marking patterns. Science 182, 939-941.

Dickman, C., 1999. Rodent ecosystem relationships: a review. In: Proceedings of the International Conference on Rodent Biology and Management, Beijing, China. Australian Centre for International Agricultural Research, Canberra, 5-9 October 1998.

Drickamer, L., 1995. Rates of urine excretion by house mouse (Mus domesticus) - differences by age, sex, social status and reproductive condition. J. Chem. Ecol. 21, 1481-1493.

Drickamer, L., 1996. Intra-uterine position and anogenital distance in house mice: consequences under field conditions. Anim. Behav. 51, 925-934.

Drickamer, L., Gowaty, P., Holmes, C., 2000. Free female mate choice in house mice affects reproductive success and offspring viability and performance. Anim. Behav. 59, 371-378.

Drickamer, L., Robinson, A., Mossman, C., 2001. Differential responses to same and opposite sex odors by adult house mice are associated with anogenital distance. Ethology 107, 509-519.

Ehman, K., Scott, M., 2001. Urinary odour preferences of MHC congenic female mice, Mus domesticus: implications for kin recognition and detection of parasitised males. Anim. Behav. 62, 781-789.

Eklund, A., 1996. The effects of inbreeding on aggression in wild male house mice (Mus domesticus). Behaviour $133,883-901$.

Elton, C., 1942. Voles, Mice and Lemmings: Problems in Population Dynamics. Clarendon Press, Oxford.

Elwood, R., 1991. Ethical implications of studies on infantidice and maternal aggression in rodents. Anim. Behav. 42, 841-849.

Elwood, R., Mason, C., 1994. The couvade and the onset of paternal care-a biological perspective. Ethol. Sociobiol. 15, 145-156.

Fentress, J., 1976. Dynamic boundaries of patterned behaviour: interaction and self organisation. In: Bateson, P., Hinde, R. (Eds.), Perspectives in Ethology. Plenum Press, New York, pp. 135-169.

Fentress, J., 1977. The tonic hypothesis and the patterning of behaviour. Ann. N. Y. Acad. Sci. 290, 370-395.

Fertig, D., Edmonds, V., 1969. The physiology of the house mouse. Sci. Am. 221, 103-110.

Fitzgerald, B., Karl, B., Moller, H., 1981. Spatial organisation and ecology of a sparce population of house mice (Mus musculus) in a New Zealand forest. J. Anim. Ecol. 50, 489-518.

Fleming, A., Craemer, G., Gonzalez, A., Lovic, V., Rees, S., Melo, A., 2002. Mothering begets mothering. The transmission of behavior and its neurobiology across generations. Pharmacol. Biochem. Behav. 73, 61-75.

Garner, J., Mason, G., 2002. Evidence for a relationship between cage stereotypies and behavioural disinhibition in laboratory rodents. Behav. Brain Res. 136, 83-92.

Gerlach, G., 1990. Dispersal mechanisms in a captive wild house mouse population (Mus domesticus Rutty). Biol. J. Linn. Soc. 41, 271-277.

Gerlai, R., 2001. Behavioral tests of hippocampal function: simple paradigms complex problems. Behav. Brain Res. 125, 269-277.

Gerlai, R., Clayton, N., 1999. Analysing hippocampal function in transgenic mice: an ethological perspective. Trends Neurosci. 22, 47-51.

Gray, S., Hurst, J., 1997. Behavioural mechanisms underlying the spatial dispersion of commensal Mus domesticus and grassland Mus spretus. Anim. Behav. 53, 511-524.

Gray, S., Hurst, J., 1998. Competitive behaviour in an island population of house mice, Mus domesticus. Anim. Behav. 56, 1291-1299.

Gray, S., Jensen, S., Hurst, J., 2002. Effects of resource distribution on activity and territory defence in house mice, Mus domesticus. Anim. Behav. 63, 531-539.

Guenther, K., Deacon, R., Perry, V., Rawlins, J., 2001. Early behavioural changes in scrapie-affected mice and the influence of dapsone. Eur. J. Neurosci. 14, 401-409.

Gyertyan, I., 1995. Analysis of the marble burying response-marbles serve to measure digging rather than evoke burying. Behav. Pharmacol. 6, 24-31.

Hafer, A., 1990. Dominance status and its influence on the bruce effect in house mice. In: Macdonald, D., Müller-Scharze, D., Natynczuk, S. (Eds.), Chemical Signal in Vertebrates 5. Oxford University Press, Oxford, pp. 271-276.

Hahn, M., Karkowski, L., Weinreb, L., Henry, A., Schanz, N., Hahn, E., 1998. Genetic and developmental influences on infant mouse ultrasonic calling. II. Development patterns in the calls of mice 2-12 days of age. Behav. Genet. 28, 315-325. 
Harkin, A., Kelly, J., Frawley, J., O’Donnell, J., Leonard, B., 2000. Test conditions influence the response to a drug challenge in rodents. Pharmacol. Biochem. Behav. 65, 389-398.

Harvey, P., Chevins, P., 1985. Crowding pregnant mice affects attack and threat behavior of male offspring. Horm. Behav. 19, 86-97.

Hayes, L., 2000. To nest communally or not to nest communally: a review of rodent communal nesting and nursing. Anim. Behav. 59, 677-688.

Henderson, N., 1970. Genetic influences on the behavior of mice can be obscured by laboratory rearing. J. Comp. Physiol. Psychol. 72, 505-511.

Hennessy, M., Vogt, J., Levine, S., 1982. Strain of mother determines long-term effects of early handling: evidence for maternal mediation. Physiol. Psychol. 10, 153-157.

Henwood, C., 1995. Fancy Mice. TFH Publications, New Jersey.

Hockley, E., Cordery, P., Woodman, B., Mahal, A., van Dellen, A., Blakemore, C., Lewis, C., Hannan, A., Bates, G., 2002. Environmental enrichment slows disease progression in R6/2 Huntington's Disease mice. Ann. Neurol. 51, 235-242.

Hoffman, R., Johnson, L., Corth, R., 1985. The effects of spectral power distribution and illuminance levels on key parameters in the male golden hamster and rat with preliminary observations on the effects of pinealectomy. J. Pineal Res. 2, 217-233.

Home Office, 1986. Code of practice for the housing and care of animals used in scientific procedures. Home Office, London.

Hopkins, M., 1953. Distance perception in Mus musculus. J. Mammal. 34, 393.

Horn, A., 2000. The Pet Mouse FAQ. Website: www.horns.freeserve.co.uk/mousenew.htm.

Hurst, J., 1987a. Behavioural variation in wild house mice Mus domesticus Rutty: a quantitative assessment of female social organisation. Anim. Behav. 35, 1846-1857.

Hurst, J., 1987b. The functions of urine marking in a free-living population of house mice Mus domesticus. Anim. Behav. 35, 1433-1442.

Hurst, J., 1990. The network of olfactory communication operating in populations of wild house mice. In: MacDonald, D., Müller-Scharze, D., Natynczuk, S. (Eds.) Chemical Signal in Vertebrates 5. Oxford University Press, Oxford, pp. 401-414.

Hurst, J., 1993. The priming effects of urine substrate marks on interactions between male house mice Mus musculus domesticus Schwarz \& Schwarz. Anim. Behav. 45, 55-81.

Hurst, J., Gray, S., Davey, P., Young, D., Corbishley, J., Dawson, C., 1997. Social interaction alters attraction to competitor's odour in the mouse, Mus spretus Lataste. Anim. Behav. 54, 941-953.

Hurst, J., Nevison, C., 1994. Do female house mice, Mus domesticus, regulate their exposure to reproductive priming pheremones? Anim. Behav. 48, 945-959.

Hurst, J., Payne, C., Nevison, C., Marie, A., Humphries, R., Robertson, D., Cavaggioni, A., Beynon, R., 2001. Individual recognition in mice mediated by major urinary proteins. Nature 414, 631-634.

Jennings, M., Batchelor, G., Brain, P., Dick, A., Elliott, H., Francis, R., Hubrecht, R., Hurst, J., Morton, D., Peters, A., Raymond, R., Sales, G., Sherwin, C., West, C., 1998. Refining rodent husbandry: the mouse. Lab. Anim. 32, 233-259.

Jensen, P., 2000. Natural behaviour and behavioural needs of farm animals. Website: http://agriculture.de/acms1/ conf6/ws5abehav.htm.

Jordan, W., Bruford, M., 1998. New perspectives on mate choice and the MHC. Heredity 81, 127-133.

Kaltwisser, M., Schitzler, H., 1981. Echolocation signals confirmed in rats. Z. Saugetierkd. 46, 394-395.

Katz, H., Davies, C., 1984. Effects of differential environments on the cerebral anatomy of rats as a function of previous and subsequent housing conditions. Exp. Neurol. 83, 274-287.

Kelliher, P., Connor, T., Harkin, A., Sanchez, C., Kelly, J., Leonard, B., 2000. Varying responses of the rat forcedswim test under diurnal and nocturnal conditions. Physiol. Behav. 69, 531-539.

Kemble, E., Bolwahnn, B., 1997. Immediate and long-term effects of novel odors on risk assessment in mice. Physiol. Behav. 61, 543-549.

Kempermann, G., Kuh, H., Gage, F., 1997. More hippocampal neurons in adult mice living in an enriched environment. Nature 386, 493-495.

Kinsley, C., Svare, B., 1986. Prenatal stress reduces intermale aggression in mice. Physiol. Behav. 36, $783-786$.

Kinsley, C., Svare, B., 1988. Prenatal stress alters maternal aggression in mice. Physiol. Behav. 42, 7-13. 
König, B., 1993. Maternal investment of communally nursing female house mice (Mus musculus domesticus). Behav. Proc. 30, 61-74.

König, B., 1994. Fitness effects of communal rearing in house mice: the role of relatedness versus familiarity. Anim. Behav. 48, 1449-1457.

König, B., Markl, H., 1987. Maternal care in house mice. I. The weaning strategy as a means for parental manipulation of offspring quality. Behav. Ecol. Sociobiol. 20, 1-9.

Koolhaas, J., Korte, S., De Boer, S., van Der Vegt, B., van Reenen, C., Hopster, H., De Jong, I., Ruis, M., Blokhuis, H., 1999. Coping styles in animals: current status in behavior and stress-physiology. Neurosci. Biobehav. Rev. 23, 925-935.

Kossut, M., 1998. Experience-dependent changes in function and anatomy of adult barrel cortex. Exp. Brain Res. 123, 110-116.

Krackow, S., Rusu, A., König, B., 2002. Microsatellites marking agonistic phenotypes in wild house mice. In: Proceedings of the First European Conference on Behavioural Biology. Muenster, Germany, 31 July-4 August.

Krackow, S., 1989. Effect of food restriction on reproduction and lactation in house mice mated post partum. J. Reprod. Fertil. 86, 341-347.

Krackow, S., 1993. The effect of weaning weight on offspring fitness in wild house mice (Mus musculus domesticus): a preliminary study. Ethology 95, 76-82.

Krebs, C., Kenney, A., Singleton, G., 1995. Movements of feral house mice in agricultural landscapes. Aust. J. Zool. 43, 293-302.

Landry, S., 1970. The rodentia as omnivores. Q. Rev. Biol. 45, 351-372.

Laurie, E., 1946. The reproduction of the house mouse (Mus musculus) living in different environments. Proc. R. Soc. Lond. B 133, 248-282.

Laviola, G., Terranova, M., 1998. The developmental psychobiology of behavioural plasticity in mice: the role of social experiences in the family unit. Neurosci. Biobehav. Rev. 23, 197-213.

Lawlor, M., 1994. A home for a mouse. Hum. Innovations Alternat. Anim. Experimentation 8, 569-573.

Lay Jr., D., 2000. Consequences of stress during development. In: Moberg, G., Mench, J. (Eds.), The Biology of Animal Stress. CAB International, Wallingford.

Lenington, S., Coopersmith, C., Williams, J., 1992. Genetic-basis of mating preferences in wild house mice. Am. Zool. 32, 40-47.

Lenington, S., Egid, K., 1985. Female discrimination of male odours correlated with male genotype at the T-locus: a response to T-locus or H-2 locus variability? Behav. Genet. 15, 53-67.

Lewis, M., Gluck, J., Bodfish, J., Beauchamp, A., Mailman, R., 1996. Neurobiological basis of stereotyped movement disorder. In: Sprague, R., Newell, K. (Eds.), Stereotyped Movements: Brain and Behaviour Relationships. Princetown Academic Press, Lawrenceville, New Jersey.

Londei, T., Valentini, A., Leone, V., 1998. Investigative burying by laboratory mice may involve non-functional, compulsive behaviour. Behav. Brain Res. 94, 249-254.

Lonstein, J., De Vries, G., 2000. Sex differences in the parental behavior of rodents. Neurosci. Biobehav. Rev. 24, 669-686.

Macdonald, D., 1984. The Encyclopedia of Mammals, vol. 2. George Allen and Unwin, London.

Mackintosh, J., 1973. Factors affecting the recognition of territory boundaries by mice (Mus musculus). Anim. Behav. 21, 464-470.

Mackintosh, J., 1978. The experimental analysis of overcrowding. In: Ebling, F., Stoddart, D. (Eds.), Population Control by Social Behaviour. Institute of Biology, London, pp. 157-180.

Mackintosh, J., 1981. Behaviour of the house mouse. In: Berry, R. (Ed.), Biology of the House Mouse. Academic Press, London, pp. 337-366.

MAFF, 1996. Code of Practice for the Prevention of Rodent Infestations in Poultry Flocks. MAFF Publications, London.

Mandillo, S., D’Amato, F., 1997. Effect of strange male occur on parental care in lactating female mice. Anim. Behav. 54, 901-910.

Manning, J., Dewsbury, D., Wakeland, K., Potts, W., 1995. Communal nesting and communal nursing in house mice, Mus musculus domesticus. Anim. Behav. 50, 741-751.

Manosevitz, M., 1970. Early environmental enrichment and mouse behavior. J. Comp. Physiol. Psychol. 71, 459-466.

Mason, G., Cooper, J., Clarebrough, C., 2001. Frustrations of fur-farmed mink. Nature 410, 35-36. 
Mason, G., Latham, N., 2004. Can't stop, won't stop: is stereotypy a reliable animal welfare indicator? Anim. Welfare. 13 (Suppl.), S57-S69.

Masuda, Y., Ishigooka, S., Matsuda, Y., 2000. Digging behaviour of ddY mouse. Exp. Anim. 49, $235-237$.

Mays, N., 1999. Your First Mouse. Kingdom Books, Portsmouth.

McGregor, P., Ayling, S., 1990. Varied cages result in more aggression in male CFLP mice. Appl. Anim. Behav. Sci. 26, 277-281.

Meehan, A., 1984. Rats and Mice: Their Biology and Control. Brown Knight and Truscott Ltd., Tonbridge, Kent.

Meek, L., Dittel, P., Sheehan, M., Chan, J., Kjolhaug, S., 2001. Effects of stress during pregnancy on maternal behaviour in mice. Physiol. Behav. 72, 473-479.

Meikle, D., Westberg, M., 2001. Social dominance rank and accessory sex glands in wild adult male house mice born to food-deprived mothers. Physiol. Behav. 72, 359-364.

Meikle, D., Kruper, J., Browning, C., 1995. Adult male house mice born to undernourished mothers are unattractive to estrous females. Anim. Behav. 50, 753-758.

Melzer, P., Smith, C., 1998. Plasticity of cerebral metabolic whisker maps in adult mice after whisker follicle removal. I: Modifications in barrel cortex coincide with reorganisation of follicular innervation. Neuroscience 83, 27-41.

Mendl, M., Paul, E., 1991a. Parental care, sibling relationships and the development of aggressive behaviour in two lines of wild House mice. Behaviour 116, 11-41.

Mendl, M., Paul, E., 1991b. Litter composition affects parental care, offspring growth and the development of aggressive behaviour in wild house mice. Behaviour 116, 90-108.

Milligan, S., Sales, G., Khirnykh, K., 1993. Sound levels in rooms housing laboratory animals: an uncontrolled daily variable. Physiol. Behav. 53, 1067-1076.

Misslin, R., Ropartz, P., 1981. Responses in mice to a novel object. Behaviour 78, 169-177.

Mucignat-Caretta, C., Caretta, A., 1999. Chemical signals in male house mice urine: protein bound molecules modulate interactions between sexes. Behaviour 136, 331-343.

Mugford, R., Nowell, N., 1972. Paternal stimulation during infancy: effects upon aggression and open-field performance in mice. J. Comp. Physiol. Psychol. 79, 30-36.

Nakamura, H., Kobayashi, S., Ohashi, Y., Ando, S., 1999. Age-changes of brain synapses and synaptic plasticity in response to an enriched environment. J. Neurosci. Res. 56, 307-315.

Namikas, J., Wehmer, F., 1978. Gender, composition of litter affects behaviour of male mice. Behav. Biol. 23, 219-224.

Nevison, C., Hurst, J., Barnard, C., 1999a. Why do male ICR (CD-1) mice perform bar-related (stereotypic) behaviour? Behav. Proc. 47, 95-111.

Nevison, C., Hurst, J., Barnard, C., 1999b. Strain-specific effects of cage enrichment in male laboratory mice (Mus musculus). Anim. Welfare 8, 361-379.

Newsome, A., Stendell, R., Meyers, J., 1976. Free-watering a wild population of house mice - a test of an Australian hypothesis in California. J. Mammal. 57, 677-686.

Noirot, E., 1974. Nest-building by the virgin female mouse exposed to ultrasound from inaccessible pups. Anim. Behav. 22, 410-420.

Nolan, P., Peters, J., Vizor, L., Strivens, M., Washbourne, R., Hough, T., Wells, C., Glenister, P., Thornton, C., Martin, J., Fisher, E., Rogers, D., Hagan, J., Reavill, C., Gray, I., Wood, J., Spurr, N., Browne, M., Rastan, S., Hunter, J., Brown, S., 2000. Implementation of a large-scale ENU mutagenesis program: towards increasing the mouse mutant resource. Mamm. Genome 11, 500-506.

Nowak, R., 1999. Walker's Mammals of the World. John Hopkins University Press, London.

Olsson, A., Dahlborn, K., 2002. Improving housing conditions for laboratory mice: a review of 'environmental enrichment'. Lab. Anim. 36, 243-270.

Olsson, A., Nevison, C., Patterson-Kane, E., Sherwin, C., van de Weerd, H., Würbel, H., 2003. Understanding behaviour: the relevance of ethological approaches in laboratory animal science. Appl. Anim. Behav. Sci. 81, 245-264.

Page, R., Holmes, E., 1998. Molecular Evolution: a Phylogenetic Approach. Blackwell Science Limited, Oxford.

Palanza, P., Parmigiani, S., Vom Saal, F., 1995. Urine marking and maternal aggression of wild female mice in relation to anogenital distance at birth. Physiol. Behav. 58, 827-835.

Palanza, P., Re, L., Mainardi, D., Brain, P., Parmigiani, S., 1996. Male and female competitive strategies of wild house mice pairs (Mus musculus domesticus) confronted with intruders of different sex and age in artificial territories. Behaviour. 133, 863-882. 
Palanza, P., Morley-Fletcher, S., Laviola, G., 2001. Novelty seeking in periadolescent mice: sex differences and influence of intrauterine position. Physiol. Behav. 72, 255-262.

Pardon, M., Gérardin, P., Joubert, C., Pérez-Diaz, F., Cohen-Salmon, C., 2000. Influence of pre-partum chronic ultramild stress on maternal pup care behaviour in mice. Biol. Psych. 47, 858-863.

Parmagiani, S., Palanza, P., Brain, P., 1989. Intraspecific maternal aggression in the house mouse (Mus domesticus): a counterstrategy to infanticide by males? Ethol. Ecol. E 1, 341-352.

Patris, B., Baudoin, C., 1998. Female sexual preferences differ in Mus spicilegus and Mus musculus domesticus: the role of familiarisation and sexual experience. Anim. Behav. 56, 1465-1470.

Pech, R., Hood, G., Singleton, G., Brown, P., 1999. Models for predicting plagues of house mice (Mus domesticus) in Australia. In: Proceedings of the International Conference on Rodent Biology and Management. Beijing, China, 5-9 October 1998

Pelikán, J., 1981. Patterns of reproduction in the house mouse. In: Berry, R. (Ed.), Biology of the House Mouse. Academic Press, London, pp. 205-230.

Perrigo, G., Belvin, L., Vom Saal, F., 1992. Time and sex in the male mouse-temporal regulation of infanticide and parental behavior. Chronobiol. Int. 9, 421-433.

Perrigo, G., Belvin, L., Vom Saal, F., 1993. Social inhibition of infanticide in male house mice. Ethol. Ecol. E 5, 181-185.

Potter, M., 1994. Control of Mice, Cooperative Extension Service, University of Kentucky, 2001.

Proctor, D., 1994. Grain Storage Techniques - Evolution and Trends in Developing Countries. FAO Agricultural Services, Rome.

Prusky, G., Reidel, C., Douglas, R., 2000. Environmental enrichment from birth enhances visual acuity but not place learning in mice. Behav. Brain Res. 114, 11-15.

Pye, T., 1993. Reproductive biology of the feral house mouse (Mus musculus) on sub-antarctic Macquarie island. Wildlife Res. 20, 745-758.

Quadagno, D., 1968. Home range size in feral house mice. J. Mammal. 49, 149-151.

Randall, C. (Ed.) 1999. Vertebrate pest management-a guide for commercial applicators (Extension Bulletin E-2050). East Lansing, Michigan State University.

Renner, M., Rosenzweig, M., 1987. Enriched and Impoverished Environments: Effects on Brain and Behavior. Springer-Verlag, New York.

Rentokil, 2001. Research and development information. Website: http://www.rentokil-initial.com/rnd/.

Ricklefs, 1999. Ecology. Freeman, New York.

Roberts, V., 1998. Long-Term Effects of Early Handling on Mice (Mus musculus) and the Maternal Mediation Hypothesis. Research Project, Oxford University.

Rogers, D., Fisher, E., Brown, S., Peters, J., Hunter, A., Martin, J., 1997. Behavioral and functional analysis of mouse phenotype: SHIRPA, a proposed protocol for comprehensive phenotype assessment. Mamm. Genome. 8, 711-713.

Ross, S., Kessler, C., Nagy, Z., Scott, J., 1966. Effects of illumination on wall-leaving behavior and activity in three inbred mouse strains. J. Comp. Physiol. Psychol. 62, 338-340.

Rowe, F., 1981. Wild house mouse biology and control. In: Berry, R. (Ed.), Biology of the House Mouse. Academic Press, London, pp. 575-590.

Rowe, F., Taylor, E., Chudley, H., 1963. The numbers and movements of house mice (Mus musculus L.) in the vicinity of four corn ricks. J. Anim. Ecol. 32, 87-97.

Ryan, V., Wehmer, F., 1975. Effect of post natal litter size on adult aggression in the laboratory mouse. Dev. Psychobiol. 8, 363-370.

Saibaba, P., Sales, G., Stodulski, G., Hau, J., 1996. Behaviour of rats in their home cages: daytime variations and effects of routine husbandry procedures analysed by time-sampling techniques. Lab. Anim. 30, 13-21.

Sales, G., Milligan, S., Khirnykh, K., 1999. Sources of sound in the laboratory animal environment: a survey of the sounds produced by procedures and equipment. Anim. Welfare 8, 97-115.

Sarna, J., Dyck, R., Whishaw, I., 2000. The Dalila effect: C57BL6 mice barber whiskers by plucking. Behav. Brain Res. 108, 39-45.

Schwartz, E., Schwartz, H., 1943. The wild and commensal stocks of the house mouse Mus musculus Linnaeus. J. Mammal. 24, 59-72.

Scott, J., Pfaff, D., 1970. Behavioral and electrophysiological responses of female mice to male urine odours. Physiol. Behav. 5, 407-411. 
Sluyter, F., van Oortmerssen, G., 2000. A mouse is not just a mouse. Anim. Welfare 9, 193-205.

Smith, J., 1981. Senses and communication. In: Berry, R. (Ed.), Biology of the House Mouse. Academic Press, London.

Southern, H., 1954. Control of Rats and Mice. 3. House mice. Oxford University Press, London.

Staats, J., 1975. The laboratory mouse. In: Green, E. (Ed.), Biology of the Laboratory Mouse. McGraw-Hill Book Company, New York.

Surgeoner, G., 1986. Rodent control in livestock facilities. Queen's Printer for Ontario, Guelph.

Timm, R., 2000. UC Pest Management Guidelines: House Mouse. Website: http://www.ipm.ucdavis.edu/ PMG/PESTNOTES/pn7483.html.

Torre, I., Bosch, M., 1999. Effects of sex and breeding status on habitat selection by feral house mice (Mus musculus) on a small Mediterranean island. Z. Saugetierkd. 64, 176-186.

Tovée, M., 1995. Ultra-violet photoreceptors in the animal kingdom: their distribution and function. TREE 10, 455-459.

Triggs, G., 1991. The population ecology of house mice (Mus domesticus) on the Isle of May, Scotland. J. Zool. 225, 449-468.

Valsecchi, P., Moles, A., Mainardi, M., 1993. Transfer of food preferences in mice (Mus domesticus) at weaning - the role of maternal diet. Boll. Zool. 60, 297-300.

Valsecchi, P., Singleton, G., Price, W., 1996. Can social behaviour influence food preference of wild mice, Mus domesticus, in confined field populations. Aust. J. Zool. 44, 493-501.

van Dellen, A., Blakemore, C., Deacon, R., York, D., Hannan, A., 2000. Environmental enrichment delays disease onset in a transgenic mouse model of Huntingdon's disease. Nature 404, 721-722.

van Loo, P., Mol, J., Koolhaas, J., van Zutphen, B., Baumans, V., 2001. Modulation of aggression in male mice: influence of group size and cage size. Physiol. Behav. 72, 675-683.

van Praag, H., Kempermann, G., Gage, F., 1999a. Running increases cell proliferation and neurogenesis in the adult mouse dentate gyrus. Nature Neurosci. 2, 266-270.

van Praag, H., Cristie, B., Sejnowski, T., Gage, F., 1999b. Running enhances neurogenesis, learning and long-term potentiation in mice. Proc. Nat. Acad. Sci. 96, 13427-13431.

van Zeegeren, K., 1980. Variation in aggressiveness and the regulation of numbers in house mouse populations. Neth. J. Zool. 30, 635-770.

Vandenberg, J., Huggett, C., 1994. Mother's prior intrauterine position affects the sex ratio of her offspring in house mice. Proc. Natl. Acad. Sci. U.S.A. 91, 11055-11059.

Vandenbergh, J., 1971. The influence of social environment on sexual maturation in male mice. J. Reprod. Fertil. 24, 383-390.

Vom Saal, F., Franks, P., Boechler, M., Palanza, P., Parmagiani, S., 1995. Nest defense and survival of offspring in highly aggressive wild Canadian female house mice. Physiol. Behav. 58 (4), 669-678.

Wahlsten, D., Metten, P., Phillips, T., Boehm II, S., Burkhart-Kasch, S., Dorow, J., Doerksen, S., Downing, C., Fogarty, J., Hen, R., McKinnon, C., Merrill, C., Nolte, C., Schalomon, M., Schlumbohm, J., Sibert, J., Wenger, C., Dudek, B., Crabbe, J., 2003. Different data from different labs: lessons from studies of gene-environment interaction. J. Neurosci. 54, 283-311.

Warburton, V., Sales, G.S.M., 1989. The emission and elicitation of mouse ultrasonic vocalisations: the effects of age, sex and gonadal status. Physiol. Behav. 45, 41-47.

Warren, J., Zerweck, C., Anthony, A., 1982. Effects of environmental enrichment on old mice. Dev. Psychobiol. $13,13-18$.

Whitaker, J., 1966. Food of Mus musculus, Peromyscus maniculatus and Peromyscus leucopus in Vigo County, Indiana. J. Mammal. 47, 473-486.

Wright, S., Brown, R., 2000. Maternal behavior, paternal behavior, and pup survival in CD-1 albino mice (Mus musculus) in three different housing conditions. J. Comp. Psychol. 114, 183-192.

Wright, S., Crawford, C., Anderson, J., 1988. Allocation of reproductive effort in Mus domesticus: responses of offspring sex ratio and quality to social density and food availability. Behav. Ecol. Sociobiol. 23, $357-$ 365 .

Würbel, H., 2001. Ideal homes? Housing effects on rodent brain and behaviour. Trends Neurosci. 24, $207-211$.

Würbel, H., Stauffacher, M., 1998. Physical condition at weaning affects exploratory behaviour and stereotypy development in laboratory mice. Behav. Proc. 43, 61-69. 
Würbel, H., Stauffacher, M., 1997. Age and weight at weaning affects corticosterone levels and development of stereotypies in ICR mice. Anim. Behav. 53, 891-900.

Young, H., Strecker, R., Emlen, J., 1950. Localisation of activity in two indoor populations of house mice, Mus musculus. J. Mammol. 31, 403-410.

Zielinski, W., Vandenbergh, J., Montano, M., 1991. Effects of social stress and intrauterine position on sexual phenotype in wild-type house mice (Mus musculus). Physiol. Behav. 49, 117-123. 